\author{
K.I. Ilyasova ${ }^{1}$, Mangazina Zh.R. ${ }^{2}$ \\ ${ }^{1,2}$ Kazakh Leading Academy of Architecture and Civil Engineering, \\ Almaty, Republic of Kazakhstan
}

\title{
ANALYSIS OF TOURISM INFRASTRUCTURE FACILITIES CONSTRUCTION IN RK
}

Annotation. This article discusses the construction of tourist infrastructure, analyzes the construction of tourism infrastructure in the Alakol recreation area and the infrastructure of highways and checkpoints on the state border of the Republic of Kazakhstan.

Key words: infrastructure, construction, tourist facilities, analysis.

The development of the tourism sector not only provides employment for the population, but also brings income to representatives of the tourism business, and also affects all areas of the economy, construction, transport and communications. The development of this industry begins primarily with the provision of infrastructure, construction of engineering systems, roads and tourism facilities.

The tourism industry is currently one of the most profitable businesses in the world. All over the world, petroleum products rank first, primarily cars, and tourism takes the third place, namely the construction of infrastructure facilities of which we are studying. It is customary to refer to infrastructure facilities in construction as auxiliary facilities that ensure the normal life of the population or the operation of residential, commercial, public, industrial buildings and structures.

On average, the income provided by one foreign tourist is equal to the output on the world market of about 9 tons of coal or 15 tons of oil or 2 tons of premium wheat. In Kazakhstan, within the framework of the state program for the development of tourism, priority tourist zones have been adopted, which are the most promising areas:

1) Lake Alakol - with a potential of $2,500,000$ tourists per year (current flow $-772,000$ tourists per year);

2) mountain cluster of the Almaty region - with a potential of $2,500,000$ tourists per year (current flow - 500,000);

3) Shchuchinsko-Borovsk resort area - with a potential of 2,000,000 tourists per year (current flow - 750,000);

4) Bayanaul resort area - with a potential of 450,000 tourists per year (current flow - 200,000);

5) Imantau-Shalkar resort area - with a potential of 400,000 tourists per year (current flow - 130,000);

6) Lake Balkhash - with a potential of 400,000 tourists per year (current flow $-130,000)$;

7) development of historical and cultural tourism in Turkestan - with a potential of 1,500,000 tourists per year (current flow -500,000); 
8) development of beach tourism in Mangystau - with a potential of 750,000 tourists per year;

9) development of MICE tourism in Nur-Sultan city - with a potential of $1,000,000$ tourists per year;

10) development of the Baikonur tourist zone as an entertainment tourist hub (hub airport) - with a potential from 250 thousand to 500 thousand tourists a year [1].

These destinations identified as key areas of tourism development, each of which has its own personality, distinctive products and/or the potential market development. According to the draft state program, the development of the selected 10 directions is a key condition for the formation of a modern highly efficient tourist complex and increasing the contribution of tourism to the economy of Kazakhstan.

Carry out an analysis on the construction of tourism infrastructure Alakol recreation area.

On the Coast of Alakol Lake, good conditions for the construction of tourist facilities and infrastructure are created. The embankment improvement works started in 2016. It should be noted that the number of tourists in the Almaty region in 2019 increased by $19 \%$ and exceeded 2.3 million people. Therefore, the volume of services rendered to guests increased by 1.2 times and reached 16 billion tenge. These indicators will be increased by creating comfortable conditions for tourists. The airport in Usharal was reconstructed, which will make it possible to receive large aircraft. On the Coast of Alakol Lake, work will be carried out to build water supply, drainage and bank protection networks.

Alakol is a large lake in the Republic of Kazakhstan. The rivers Katynsu, Urdzhar, Zhamanty, Zhimayty, Emelkuysa, Zhamanotkel flow into the lake, but not a single river flows out, therefore Alakol Lake is called closed. The lake is called «Alakol» for a reason, because its color changes during the day, from blue in the morning to purple at sunset, on sunny days the lake is filled with bright colors of summer, and on cloudy days - grayish-black.

Recreation centers strive to improve the quality of the service provided, expand the range of services, build swimming pools, playgrounds, cafes, etc.

Alakol is located between the Dzhungarskiy Alatau and the Tarbagatai mountain system, east of the city of Usharal.

The lakes are part of the ecosystem of the state reserve. Recreation areas are located on two shores of Lake Alakol - from the East Kazakhstan region (Kabanbay, Zharbulak) and on the southwestern coast (Akshi and Koktuma) [2].

In the Alakol region, 8 projects were subsidized in the first direction of the «Business Roadmap 2020» program:

- Construction of a hotel complex;

- Construction of a recreation area on the shore of Lake Alakol;

- Acquisition of real estate for business organization;

- Redecoration of the recreation area, purchase of fixed assets. In 2017, 1 billion 109.1 million tenge was allocated from the budget for the road construction 
of the embankment of Lake Alakol, and 723 million tenge were allocated to complete the construction of the airport in Usharal [3].

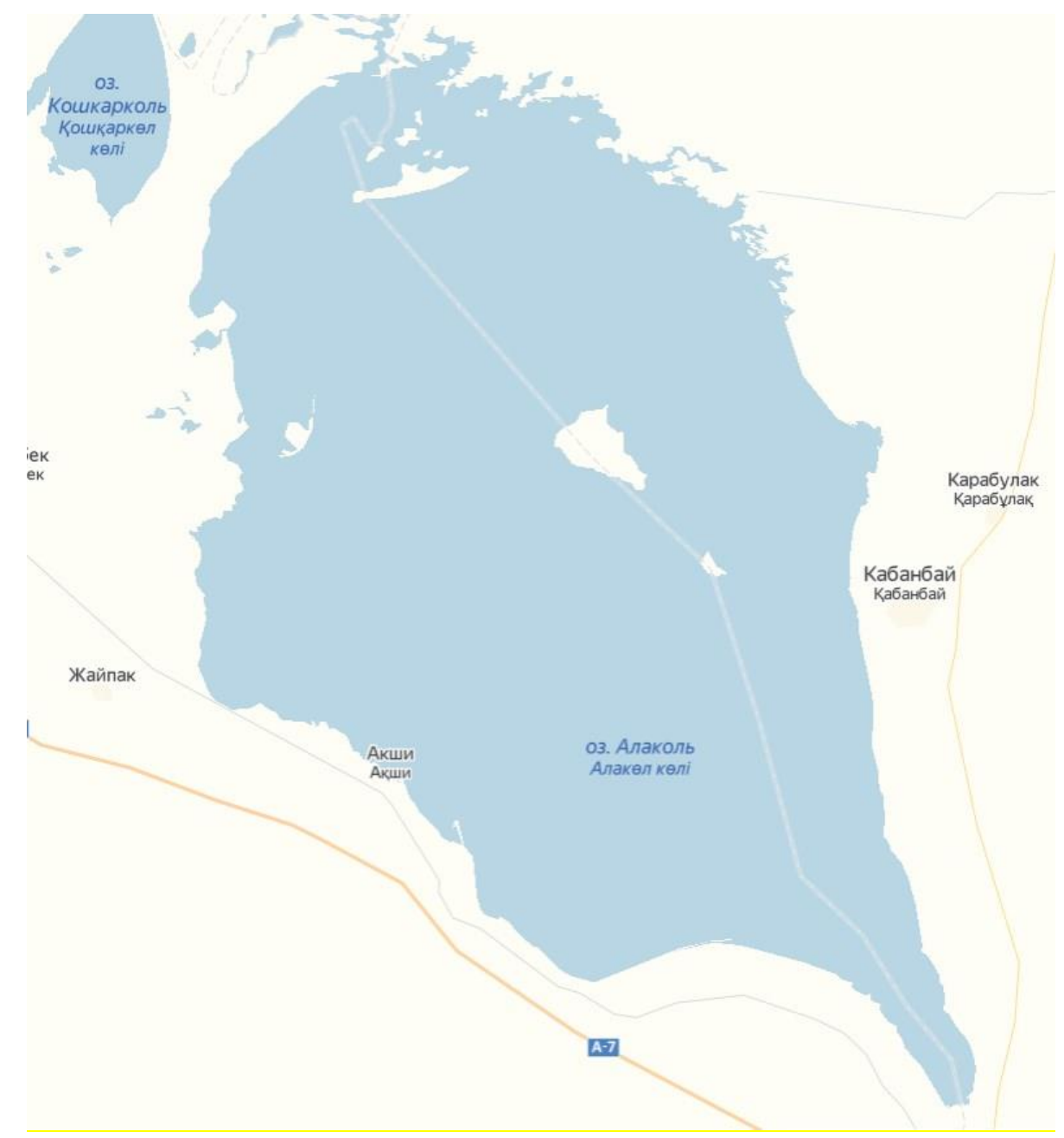

Figure 1 - Alakol - parts in Almaty region and East Kazakhstan region

In order to improve the comfort of recreation, the construction of many large infrastructure facilities was planned for 2020, due to the global pandemic, construction has been postponed. In addition, it is planned to implement projects worth 30 billion tenge, including the construction of about two kilometers of waveguide, water supply, sewerage systems and water intake facilities, construction of water filtration fields. Also, the construction of a 110 kilowatt electrical network is envisaged as infrastructure facilities in the section from the village of Makanchi to the village of Koktal.

Within the framework of the state program, Semey is carrying out repair work on the roads from Ust-Kamenogorsk to Alakol. The construction of bicycle paths $2.6 \mathrm{~km}$ long, 6 meters wide, which will connect the Kabanbai and Alakol embankments, are envisaged.

The resort coast of Alakol belongs to a seasonal type of activity; at present, it is planned to build a health-improving complex that can be serviced in the winter.

Construction project of recreation area in Alakol district of Almaty region. 

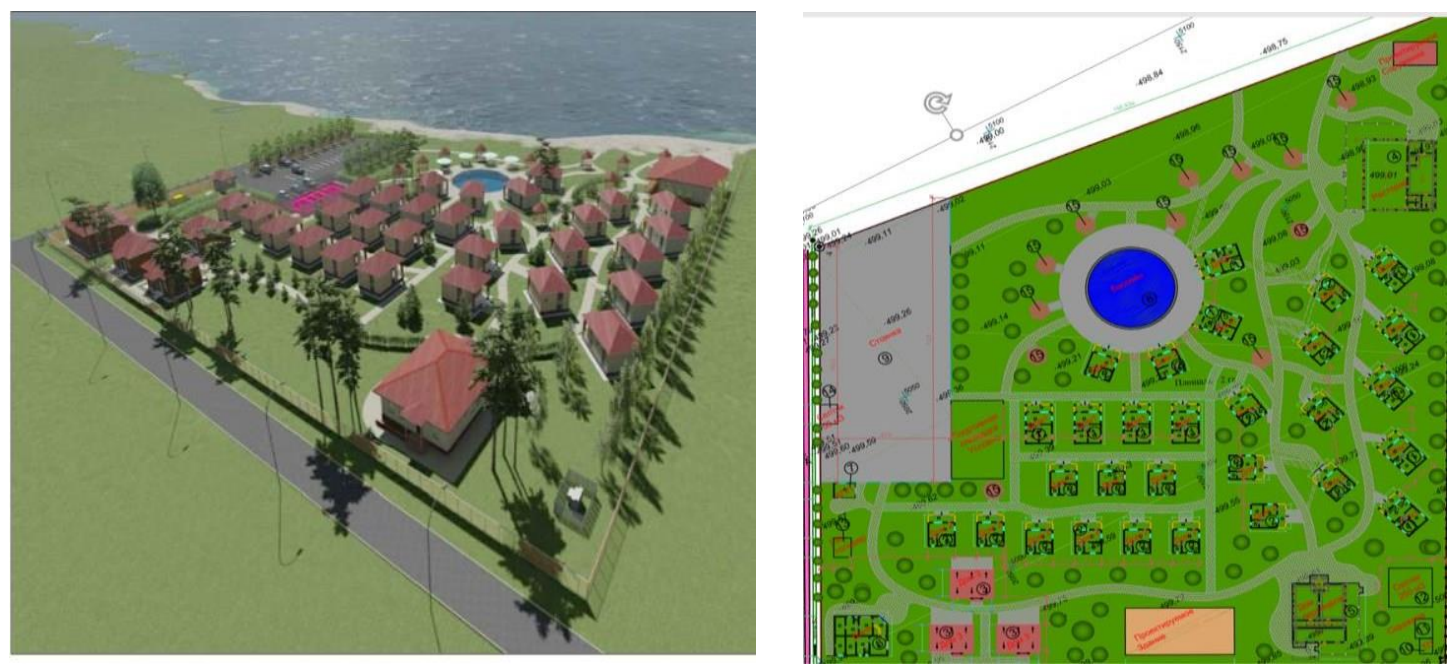

Figure 2 - Construction project of recreation area

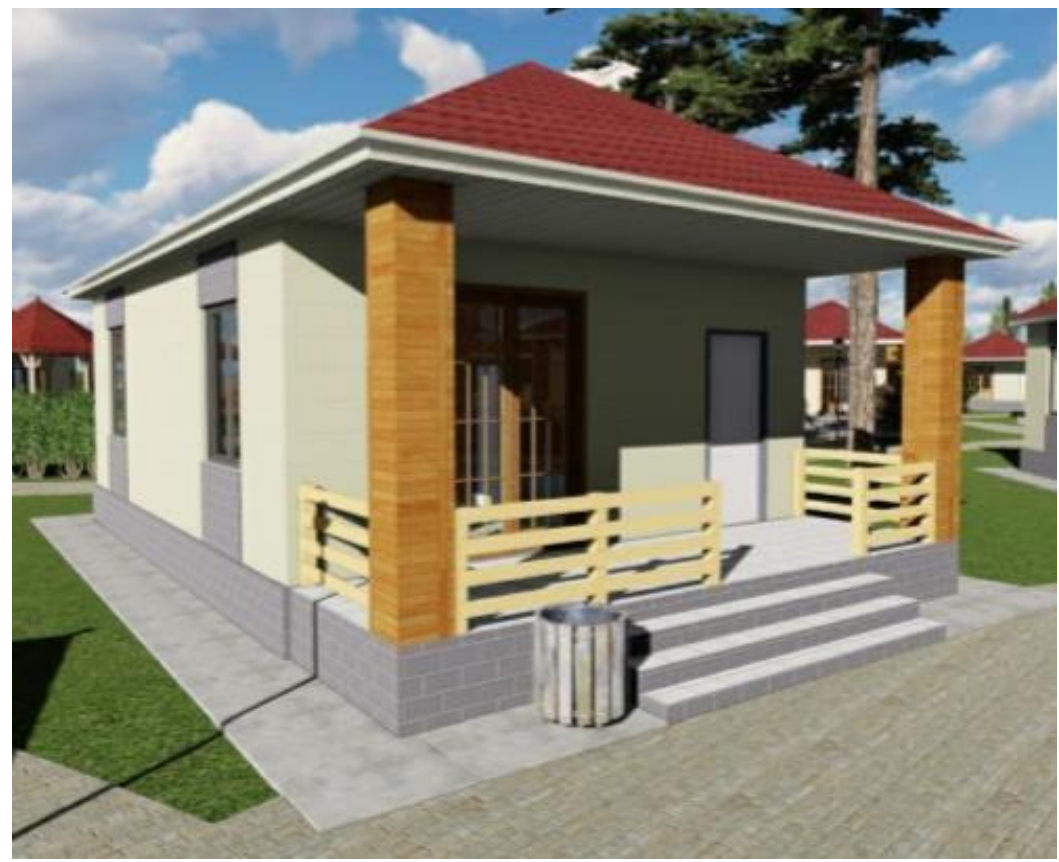

Figure 3 - Facade of a type 1 house

Table 1 - Explication of buildings and structures

\begin{tabular}{|l|l|c|c|}
\hline № & \multicolumn{1}{|c|}{ Nomination } & Quantity & Number of storeys \\
\hline 1. & Country house type 1 & 11 & 1 \\
\hline 2. & Country house type 2 & 18 & 1 \\
\hline 3. & Winter house & 3 & 1 \\
\hline 4. & A restaurant & 1 & 1 \\
\hline 5. & House of employees & 1 & \\
\hline
\end{tabular}


QazBSQA хабаршысы. Құрылыс конструкциялары және материалдары 4 (78) 2020

\begin{tabular}{|l|l|c|c|}
\hline 6. & Bath & 1 & 1 \\
\hline 7. & Checkpoint & 1 & 1 \\
\hline 8. & Pool & 1 & \\
\hline 9. & Parking & 1 & \\
\hline 10. & Transformer & 1 & \\
\hline 11. & Well & 1 & \\
\hline 12. & Septic tank for $250 \mathrm{~m}^{3}$ & 1 & \\
\hline 13. & Gas holder & 12 & \\
\hline 14. & Septic tank for $50 \mathrm{~m}^{3}$ & & \\
\hline 15. & Alcove & & \\
\hline
\end{tabular}

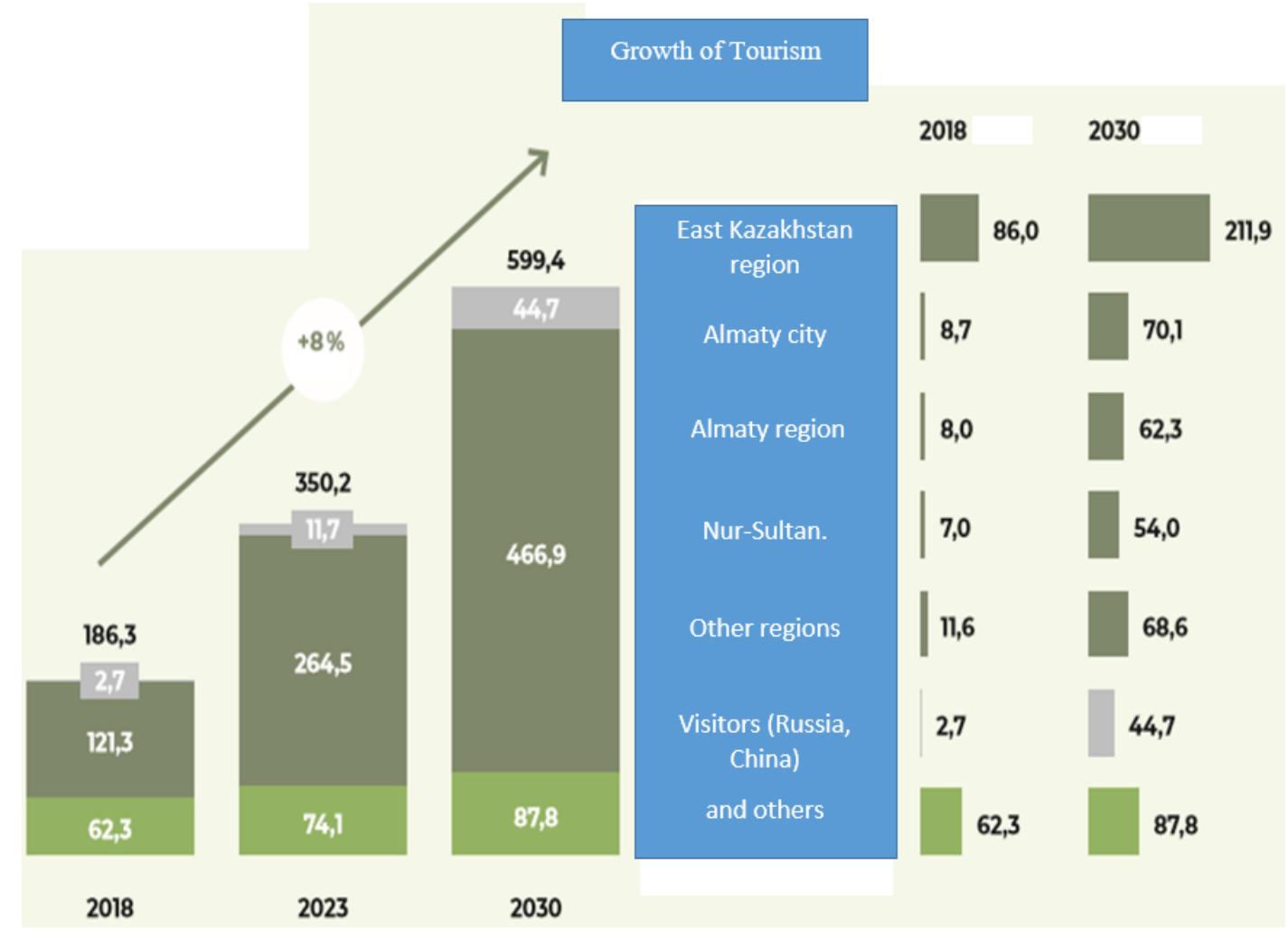

Figure 4 - Development of tourism on the coast of Alakol

Table 2 - Basic construction indicators

\begin{tabular}{|c|l|c|}
\hline № & \multicolumn{1}{|c|}{ Indicator of nomination } & Quantity $\left(\operatorname{area~m}^{2}\right)$ \\
\hline 1 & Number of storeys & 1 \\
\hline
\end{tabular}


QazBSQA хабаршысы. Кұрылыс конструкциялары және материалдары 4 (78) 2020

\begin{tabular}{|c|l|c|}
\hline 2 & Construction site & $62,0 \mathrm{~m}^{2}$ \\
\hline 3 & total area & $54,3 \mathrm{~m}^{2}$ \\
\hline 4 & Construction capacity & $217,0 \mathrm{~m}^{2}$ \\
\hline 5 & The area of the land & 2,0 hect \\
\hline
\end{tabular}

According to the forecast of tourism development in the Alakol region, the number of visitors will increase (Fig. 3.) and the project for the construction of a recreation area is very profitable, investments in the project will pay off in two years. For example, the area of a type 1 country house in the project is $54 \mathrm{~m}^{2}$. Of these: kitchen area-studio $-17.4 \mathrm{~m}^{2}$; corridor area $-2.5 \mathrm{~m}^{2} ; 1$ bedroom area $-12.5 \mathrm{~m}^{2}$; area of 2 bedrooms $-8.4 \mathrm{~m}^{2}$; bathroom area $-2.7 \mathrm{~m}^{2}$; terrace area $-10.8 \mathrm{~m}^{2}$, according to our calculation, the estimated cost is 7,932,550 tenge.

We will analyze the infrastructure of highways and checkpoints on the state border of the Republic of Kazakhstan.

According to the Ministry of Industry and Infrastructure Development of the Republic of Kazakhstan, at present, the length of the public road network in Kazakhstan is 95.6 thousand kilometers, of which 24.4 thousand kilometers of republican significance and 71.2 thousand kilometers of regional and district significance [4].

In order to meet the needs of the economy, the population in high-quality and low-risk state automobile services, as well as in transit - energy efficient means of the Kazakhstan industry, there are a number of programs - the state program for the development of the motor transport industry of the Republic of Kazakhstan (2001), the state program for the development of transport routes of the Republic of Kazakhstan (2005).

Programs were approved to create conditions for transport links in the Republic of Kazakhstan. At the aforementioned level of the republic, more than twenty kilometers of roads passing through our country have been repaired for the most important programs, more than eleven thousand labor resources have been involved.

2567.8 billion were spent on road repair, of which 800 billion tenge from the country's budget, which are listed below:

More than 8 thousand $\mathrm{km}$ were reconstructed between «Almaty - NurSultan», «Nur-Sultan - Kostanay - Chelyabinsk», «Samara - Shymkent», «Atyrau - Uralsk», «Aktobe - Karabutak - border of Kostanay region», «Almaty - Bishkek», «Atyrau - Aktau», «border of the Russian Federation - Pavlodar - Maykapshagai», «Taskesken - Bakhty», «Shonzhi - Kolzhat», «Shchuchinsk - Kokshetau», «Kyzylasker-Kirov», «Northern and Southern bypass of Nur-Sultan city», etc.

Bridges were built across the rivers Ural, Syrdarya, Kigach, and Irtysh in Pavlodar.

80,000 people were involved in the construction work to repair the roads, $95 \%$ of the materials were attracted by domestic products. The total amount of allocated money is 932.4 billion tenge. The construction and repair of republican and local roads is carried out in a planned and systematic manner. 
The condition of highways of republican importance has improved by $86 \%$, at the regional level, the roadbed at $66 \mathrm{~km}$ has been repaired and improved, which indicates an improvement of highways by $40 \%$ at the level of the entire republic.

At the same time, it is necessary to continue work to ensure transport accessibility, improve quality, reliability and create favorable conditions for the provision of services to the population in all areas of activity. Regional strategies for the development of the tourism product should be considered, and priority should be given to the construction of tourism facilities and tourism infrastructure.

\section{References:}

1. Қазақстан Республикасының туризм саласын дамытудың 2019 - 2025 жылдарва арналzан Мемлекеттік бавдарламасы http://adilet.zan.kz/kaz/docs/P1900000360

2. Пяткова С.Г. Основы туризма: учеб.-метод. пособие / С.Г. Пяткова. - Электрон. текстовые данные. - Саратов: Ай Пи Эр Медиа, 2019. - 151 с.

3. $\quad$ stat.gov.kz

4. adilet.zan.kz/kaz http://adilet.zan.kz/

Бұл мақұлада туристік инфрақұрылым объектілері құрылысы құарастырылван, Алакөл демалыс аймавында туризм инфрақұрылымы объектілері мен ҚР мемлекеттік шекарасындагы автомобиль жолдары мен өткізу пункттерінің инфрақұрылымын құрыльстарына талдау жүргізілген.

Түйін сөздер: инфрақұрылым, құрылысс, туристік объектілер, талдау.

В данной статье рассматривается строительство объектов туристской инфраструктуры, проведен анализ строительства объектов инфраструктуры туризма в Алакольской зоне отдыха и инфраструктуры автомобильных дорог и пунктов пропуска на государственной границе $Р К$.

Ключевые слова: инфраструктура, строительство, туристские объектьи, анализ. 